\title{
Black Administrators in Higher Education: Autoethnographic Explorations and Personal Narratives
}

Edited by: Terence Hicks and Lemuel Watson

Published by: The Rowan \& Littlefield Publishing Group, Inc., 2018, 105 pages

Reviewed by: Lisa N. Jackson, Ed.D., Interim Director of New Student Programs at University of Illinois Urbana - Champaign

Hicks and Watson (2018), both former deans of education, have compiled a book that uniquely shares the stories of seven Black higher education professionals. Their book begins to empty a void that has existed for years. One of the most important takeaways for me in reviewing this book is the level of authenticity and transparency provided by the authors of the chapters. Using the qualitative methods of autoethnographic explorations and personal narratives, the writers share their experiences of being a Black administrator in higher education.

In 2016, College and University Professional Association for Human Resources (CUPA - HR) found that 7\% of higher education administrative positions were held by Black professionals (Seltzer, 2017). As institutions of higher learning have been seeing an increase in underrepresented populations, more specifically Black students, conversations continue to happen around the disparity of Black administrators in higher education. Black Administrators in Higher Education is a series of stories from six Black administrators in a higher education setting and a recent doctoral graduate. The writers share their journey to senior level administrative 
positions or their perspective as a student who has been affected by the changes in deanship. In this book, Hicks and Watson provide snippets of the obstacles Black higher education professionals face when they desire to be a high-level administrator.

While the stories in the book are primarily shared from Black professionals who are on the academic side of institutions, there is one chapter written by a student affairs professional, J. Michael Harpe. Harpe, a former vice president of student affairs, provides a unique overview of his tenure as an administrator and faculty member. He shares with the reader a transparent viewpoint of the characteristics that an individual must possess to be successful. Harpe shares "...if a university wants to continue to promote a community of scholars and educators, there must be a meticulous effort to collaborate" (p. 92). Harpe provides an oversight of challenges faced by many institutions. Additionally, he briefly discusses the content areas of leadership experience, management experience, collaboration, and advocacy and the importance they play in being an effective leader helping to move forward an institution's mission.

Chapters 1-4 and Chapter 6 are written by Black administrators who serve as deans at a variety of public or private, two-year or fouryear institutions. In some chapters, the author has shared research they have conducted about some aspect of Blacks in higher education. In each chapter, the authors are prompted to answer a question about their journey. It is within these questions that the authors are given the opportunity to share an in-depth overview of how they see leadership and how it prepared them for their current position.

Chapter 1 was the only chapter that had two writers who provided their perspective on servant and shared leadership. One author, Doyin Coker-Kolo, has worked as an administrator and faculty member, both internationally and in the United States. She shares her experiences working in higher education and the challenges she faced when she began working at her first institution in the United States. This chapter may be of interest to those aspiring to work in higher education internationally and provide them with some insight on the differences that exist from this author's viewpoint. 
Research is also scarce on Black females in senior level positions in higher education. In Chapter 4, Tawannah Allen shares what she calls "pearls of wisdom from successful women of color" (p. 46). Allen's chapter focuses on research conducted using the Critical Incident Technique and provides an analysis of experiences from 34 women of color who were at the highest point of their careers. This chapter provides insight on the challenges women of color may face when looking to grow professionally.

Chapter 5, written by a recent doctoral student, also provides an interesting perspective from someone who experienced four deans within three years. Jasmine Williams, who was a student at a historically black institution in Texas, shares how the instability in leadership within three years impacted faculty, staff, and students. Williams shares how, due to the abrupt changes the unit faced, not only did morale decrease but priorities shifted and the weaknesses within leadership became more visible. Similarly, to Chapter 1, Williams talks about the importance of shared governance in a higher education setting.

While I believe this book could have chapters more evenly dispersed between professionals in academia and student affairs, one theme that emerged from all chapters was the value of effective and authentic leadership. The writers convey that their success was dependent on the type of leadership they were engaged with. By gaining an understanding of self, personally and professionally, they have been able to mold themselves into being the type of leader they desire to be.

Being an administrator in higher education, I know there is a gap in research discussing the journey of Black administrators in the field. While this book shares the stories of six administrators and one doctoral student who work at a variety of schools, including predominately white institutions and historically black colleges, it heavily discusses the stories of individuals whose primary work is as a faculty member or an administrator in academics. The information can be interchangeable; however, this book seems to be catered to Blacks interested in progressing as an administrator within academic affairs versus student affairs.

This book adds to a set of resources that are currently limited; however, having only one chapter focusing on the profession of student 
affairs is a disservice. Understandably, there can be some overlap in the challenges faced and this book was an opportunity for narratives to be shared from both perspectives. Although there is a value to a book of this nature, I argue that it would have been more appealing if there could have been additional stories shared from professionals who don't work as an administrator within an academic college. Although the chapters are primarily written by colleagues who are in academia, I do not want to minimize the value and lessons that can be learned from their stories. Black Administrators in Higher Education is a good resource for professionals who have an interest in pursuing a career in an academic college.

In summary, this book provides a good insight into what one may face if they choose to pursue a senior level administration position within higher education. Understandably, not everyone's journey to these higherlevel positions will be the same. Readers will be able to gain insight on some of the obstacles they may face if they choose to follow the path of becoming a senior level administrator and will get a glimpse of how others have successfully navigated their way to these positions.

\section{References}

Allen, T. (2018). Ascending to Leadership Positions in Higher Education: Pearls of Wisdom from Successful Women of Color. In Editor Hicks, T. \& Watson, L. (Eds.), Blacks in Higher Education: Autoethnographic explorations and personal narrative (pp. 45 - 62). Lanham, MD: The Rowan \& Littlefield Publishing Group, Inc.

Harpe, J.M. (2018). The Progeny of Administration. In Editor Hicks, T. \& Watson, L. (Eds.), Blacks in Higher Education: Autoethnographic explorations and personal narrative (pp. 91 - 99). Lanham, MD: The Rowan \& Littlefield Publishing Group, Inc.

Seltzer, R. (2017, March 2). Racial Gap Among Senior Administrators Widens. Retrieved from https://www.insidehighered.com/news/ 2017/03/02/racial-gap-among-senior-administrators- widens. 